\title{
“EMPATHY has Biological Foundations, but Culture Determines Who WiLl be THE SUBJECT OF THAT IDENTIFICATION"*
}

\author{
"A empatia tem fundamentos biológicos, mas a cultura \\ determina quem está sujeito a essa identificação"
}

\author{
LYNN HUNT ${ }^{1}$ \\ Cilza BignotTón \\ Carlos Cortez Minchillo ${ }^{3}$ (iD \\ ${ }^{1}$ University of California, Los Angeles (UCLA), CA, United States. \\ E-mail:1hunt@history.ucla.edu \\ ${ }^{2}$ Universidade Federal de São Carlos (UFSCAR), Departamento de Letras. São Carlos, SP, \\ Brasil. \\ E-mail: cilzab@gmail.com \\ ${ }^{3}$ Dartmouth College, Departamento de Espanhol e Português. Hanover, NH, United States. \\ E-mail: minchillo@dartmouth.edu
}

EDITORES:

Regina Zilberman

Gerson Roberto Neumann

SUBMETIDO: 25.03 .2021

ACEITO: 12.04 .2021

\section{COMO CITAR:}

HUNT, Lyn; BIGNOTO, Cilza; MINCHILLO, Carlos Cortez. "Empathy has biological foundations, but culture determines who will be the subject of that identification”. Rev. Bra. Lit. Comp., Porto Alegre, v. 23 , n. 43 , p. 134-139, mai.ago., 2021. doi: https: / / doi.org/10.1590/2596304x20212343lhbcccm

\begin{abstract}
Can literature promote identification with the suffering of others and an empathetic connection between readers and fictional characters? Can this sentiment of sympathy translate into social solidarity and have political consequences? In this interview, professor and historian Lynn Hunt discusses the interplay between literature and human rights and reflects on our relationship to history, the fragility of democracy, and the self and society duality.

KEYWORDS: Human rights, theory, empathetic reading, literature and history.

\section{RESUMO}

Pode a literatura promover a identificação com o sofrimento alheio e uma relação empática entre leitores e personagens ficcionais? Pode esse sentimento de simpatia traduzir-se em solidariedade social e ter consequências políticas? Nesta entrevista, a professora e historiadora Lynn Hunt discute as relações entre literatura e direitos humanos e reflete sobre a nossa relação com a história, a fragilidade da democracia e a dualidade entre self e sociedade.
\end{abstract}

PALAVRAS-CHAVE: Direitos humanos, teoria, leitura empática, literatura e história.

* Interview conducted in 15 February 2021 to Cilza Bignoto and Carlos Cortez Minchillo 
$\mathrm{n}$ a passage from one of her most recent books, History, Why It Matters? (2018) historian Lynn Hunt recalls a time at College when she and her friends used to speculate what it would have been like to live in Nazi Germany. "Would I have resisted or turned a blind eye to what was happening to Jews, communists, homosexuals, Roma, and the disabled?” The question prefigures Hunt's interest around empathy and her investigation on what can trigger social solidarity. In her acclaimed study Inventing Human Rights (2007), Hunt analyses how the eighteenth-century epistolary novels enabled readers to empathize across class, sex, and national lines and therefore contributed to the emergence of human rights. The granting of rights to some groups has led and continues to lead to demands from excluded groups. "The promise of these rights can be denied, suppressed or simply remain unfulfilled," she writes, "but it doesn't die".

Hunt, a distinguished research professor at UCLA, has extensively published about the French Revolution: Revolution and Urban Politics in Provincial France (1978); Politics, Culture, and Class in the French Revolution (1984); The Family Romance of the French Revolution (1992); The French Revolution and Napoleon: Crucible of the Modern World (2017), co-authored with Jack R. Censer. She has also been concerned with historical method and epistemology: The New Cultural History (1989); with Joyce Appleby and Margaret Jacob, Telling the Truth about History (1994); with Jacques Revel, Histories: French Constructions of the Past (1995); and with Victoria Bonnell, Beyond the Cultural Turn (1999).

In this interview conducted by e-mail in March 2021, Hunt revisits the connections between literature, empathy and human rights, and comments about how those topics can illuminate presentday issues. We are grateful to her for taking the time during the pandemic to answer our questions.

\section{RBLC: In Inventing Human Rights, you suggest that the epistolary novel was uniquely suited to provoke the kind of empathic response that fostered the idea of human rights in the 18th century. You also point out that empathy has been undermined by sensationalism and radical ideologies of difference in modern times. Is there any fictional genre today that could still engender empathy?}

Lynn Hunt: Actually, I think that the novel can still produce empathetic identification across gender, racial, and ethnic lines, not to mention of course, chronological ones. In the eighteenth century most novels were set in the present time; the historical novel came into being in the early $19^{\text {th }}$ century - think of Walter Scott - and one could argue in reaction to the French Revolution. Perhaps by definition, any work of imagination is capable of producing empathetic identification, but in my work on human rights I was most interested in the new effort to create identification with characters who were not heroic in any traditional sense (not adventurers or warriors, not, in particular, men). In our time, film and television can have some of the same effects (and theater continues to do so), depending on the narrative strategies that are used. There is no question that drama, whether live or filmed, and perhaps especially "soap opera" or "melodrama" encourage identification with characters, so if women, nonwhites, or working-class characters are foregrounded, identification can take place with characters not usually seen as heroes. I have just been watching the Netflix series Shtisel, for instance, which is about an orthodox Jewish community in Jerusalem. I have no sociological reason to identify with the characters but I find that I do nonetheless because of the artistry of the series makers. This kind of identification leads to greater understanding, I believe, of people who are different from yourself because they have feelings that are familiar to you (tensions with parents or siblings, desire to be loved, etc.). 
RBLC: In your study, you comment that Sade's works, compared with Richardson's, do not generate empathy; instead, they evoke a different range of emotions. Are these different responses embedded in the narratives or are they a result of extraliterary factors and ultimately depend on the reader?

LH: I believe that these different responses are produced by narrative strategies. In Sade, though there is certainly room for disagreement on this, the reader is compelled to identify with the actor (who can be female as well as male but is usually male), that is, the person who arranges or orchestrates the action, the predator in sexual terms. You can identify with the victim but that in a sense labels you as the passive person in the scenario, the one who has less than complete understanding, the one who is used rather than the user. Sade does want to make you think but he does this through direct erotic stimulation and through the satirical rendition of typical $18^{\text {th }}$ century novelistic plots (e.g., instead of sex being continually deferred, it is never deferred, and it is unrelated to love or marriage).

RBLC: In some passages of Inventing Human Rights, you suggest that empathy has biological foundations. Why, then, did the invention of human rights occur in the specific context of prerevolutionary France? Could there be older roots for the idea of human rights - for example, in the compassion preached by Christianity or in human dignity (re)discovered in the Renaissance?

LH: Empathy has biological foundations, but culture determines who will be the subject of that identification and how wide or narrow identification will reach. What happens in the eighteenth century is a growing sense that many people, perhaps everyone, can achieve some form of autonomy or at least a desire for it. And that is what the reader is identifying with, that desire for autonomy. Rights come about in part through that sense of identification (that everyone has the desire for autonomy) and in part through political crisis that makes the discussion of the foundations of government more salient. Under traditional monarchies, the foundation of government was tradition itself, justified by Christian doctrine, and reproduced through family, work, and community relationships. Once those are questioned, the issue is what should be the foundation of government and the guarantee of rights is one possible answer thanks to thinking that developed over the $16^{\text {th }}, 17^{\text {th }}$ and $18^{\text {th }}$ centuries, especially about natural law and natural rights (which itself developed in response to the crisis posed by the Reformation). Christian compassion was not enough because it could be cast as having no political repercussions (in traditional doctrine). Human dignity as rediscovered in the Renaissance is an important element because it feeds into the notion of individual autonomy (that dignity comes from reason exercised by autonomous individuals). Empathy, in that sense, was never enough. First, empathy had to have a broader social purview and then it had to be framed within a political discourse that challenged the foundations of traditional rule.

RBLC: George Steiner, in the well-known essay “To Civilize Our Gentleman,” declares that "the death in the novel may move us more potently than the death in the next room. Thus, there may be a covert, betraying link between the cultivation of an aesthetic response and the potential of personal inhumanity." Is the disconnect between aesthetic appreciation and ethical behavior a product of certain periods in history? If so, what circumstances promote that disconnect? 
LH: This is a key question and there is no one answer to it. There is no question that the aesthetic response in itself is never enough which is why I have tried to emphasize the political framing of it. But there is something lacking in Steiner's formulation, nonetheless, and that is a question about the death in the next room. Why doesn't it move us if that is the case? Is it revulsion at the actual tactile experience of death (thinking for example of the death of a parent which is not easy to experience in person) or, as Steiner is implying, inability to feel sorry for the person dying? These are very different responses. The first is about fear overwhelming a feeling and the second is about something that is blocking a feeling and that something is often learned hatred (for a foreigner, a refugee, a different ethnic group, etc.). What happened in response to the $18^{\text {th }}$ century formulation of human rights was the development of a seemingly unending series of doctrines of hate - why others aren't really human after all. This process continues, as we know all too well, today.

RBLC: In response to state violence towards minorities and increasing economic inequity, there has been an upsurge in the demand for equal rights and a more inclusive society. At the same time, we witness a backlash against human rights and the rise of undemocratic regimes worldwide. Also, the notion of individual rights is often used to undermine social solidarity, as it's happening with the denouncement of mask mandates during the pandemic. Do you think it is still possible to establish some consensus about human rights and social solidarity? Can literature still play a role in that task? Or are our attitudes and sensibilities now shaped by other textual genres, languages, and media?

LH: There is probably never a consensus about human rights and social solidarity. For me the key thing about human rights is that it produces an arena for discussion and debate: who has rights, what kind of rights, and what are their limits? Mask mandates are not unlike the question of smoking: what matters is what happens in public. No one is making you wear a mask at home unless you want to do so. But all kinds of measures of public health are necessary and justifiable: you cannot burn trash so that the smoke goes into your neighbor's house; you cannot smoke in public places where the smoke might endanger the health of those present and similarly you have to wear a mask if not wearing one will endanger other people. The reason that rights generate so much debate is that they inevitably run up against social concerns. But this is true about all our social customs. We do not need to wear clothes at home but if you run naked through the streets you will get in all kinds of trouble. You can put anything you want in your own food but you cannot poison the food of others. And so on. Literature can highlight these kinds of conflicts and help us understand them because literature is often about people who feel they don't fit in to the customs of their time.

RBLC: In their fight for visibility and inclusion, underrepresented and disenfranchised groups not only contributed to expanding the literary and artistic canons but also challenging modes of fictional representation. Juvenile works from the past have been edited, and authors have been censored for depicting behaviors that many condemn today. A recent TV series, Bridgerton, took a different approach and included Black aristocratic characters in a plot revolving around 19thcentury Britain. What's your view on attempts to interfere in the past, either through making changes to existing works or through adopting a fantasy approach to history? 
LH: This is a very vexed question. I believe that it is useful to point out the limitations of past authors (the anti-Semitism of Voltaire or the racism of Jefferson) without denying their contributions to our culture and politics. Voltaire and Jefferson were incredible visionaries who pointed out many of the evil customs of their own time (without, however, being entirely blameless themselves). We will be found wanting by future generations, perhaps for the way we have trashed the planet earth, or tortured animals in order to make use of them as food or clothing, or for something we don't yet understand. Bridgerton was fascinating for at least two reasons: 1) it called attention to our usual expectations by deliberately challenging them and 2) it called attention to historical truths that have been obfuscated (some people of the time were mixed race).

RBLC: In Writing History in the Global Era, you discuss how the attention to the self can develop new perspectives on history. What are the new questions that this approach prompts us to ask? How do these questions impact our understanding of artwork and other documents from the past?

Lynn Hunt: I am still fascinated by the self-society duality, that is, that interest in the autonomy of the self grew at the same time that people began to realize that they were shaped by social circumstances. The self gained autonomy, if you will, just when people learned that even autonomy was a socially determined feeling. In other words, the rise of social science (from the $19^{\text {th }}$ century onward) is itself the product of very particular historical circumstances: the western search for an alternative foundation of social and political order (alternative, that is, to religion or tradition). The idea that this will reign triumphant forever is surely mistaken because if it is produced by history it will probably also be undone by history. As we have seen democracy (the political order of the autonomous individual) is a fragile construction, easily undone, precisely because determining the will of the people is no simple matter. I think that more attention to this self/society duality will help us to think through our current dilemmas: what are the limits of individual rights, what is the foundation of the social and political order, how do we best determine the will of the people and what are our responsibilities as individuals to the social order (and should this social order be seen as one of our neighborhood, our region, our nation, our world, just our species or all of them but in what order of priority?)?

\section{RBLC: In an interview with Nicholas D. Chabraja Center for Historical Studies, you said that} you once thought you were going to be a German Literature Major - then switched to History. Were there any literary works that made you empathize with ideas different from your own? If so, what were the books that most marked you?

LH: I began as a German literature major because my maternal grandparents were German speakers, my grandmother having been born in the US at the end of the $19^{\text {th }}$ century into a recently immigrated family, and my grandfather immigrating himself from a German speaking region of Ukraine (then known to us as the USSR). I switched to French history because of an interest in revolution (I was a student in the 1960s and very much shaped by that era) and I have never regretted it. France was a fascinating place because of the influence of decolonization, Marxism, and "French theory" as it developed over time. If I were a student now it would be hard to predict what I would choose. Most likely I would want to do something more global, though French being then a language of international politics and diplomacy, it was a good place to start. I would probably pay more attention to the Spanish-speaking 
world because after all I was born in Panama and both my parents learned Spanish because they spent many years in Panama (my mother with the US army during World War II and my father as a private citizen working as an engineer).

As for books, I began with a very strong interest in Marxism, learned Italian in order to be able to read Gramsci in Italian, read all the works I could of Marx, Lenin, Mao, etc. As a young girl and early teenager, however, I went to the public library in St. Paul and read down the row: I read all of Fitzgerald (who came from St. Paul), Hemingway, Stein, Steinbeck, Ford Maddox Ford, and Henry James. But also Dostoyevsky, Solzhenitsyn, Pasternak and even Sholokov. When I went to France to work on my PhD dissertation, I read all of I could of Balzac, Flaubert, Stendhal, Roger Martin du Gard, de Beauvoir and Sartre. I only really seriously read eighteenth-century literature when I began teaching: Richardson, especially, and Rousseau's Nouvelle Héloïse. I now read more eclectically as I find I enjoy Indonesian, Malaysian, Egyptian, Swedish and South American novels as much as I once did the others. I also read endless numbers of police procedurals but not thrillers. I can't stand to read things that are really scary. What I love about reading novels is just what Diderot said of them, when it's over you are very sad to have to leave that world which seemed so real to you. It's not just an escape from your own current life. It's a feeling of being transported (similar to the feeling generated by very successful television series).

\section{REFERENCES}

APPLEBY, Joyce;JACOB, Margaret; HUNT, Lynn (ed.). Telling the Truth about History. New York; London: W.W. Norton, 1994.

BONNEL, Victoria; HUNT, Lynn. Beyond the Cultural Turn: New Directions in the Study of Society and Culture. Berkeley; Los Angeles: University of California Press, 1999.

CENSER, Jack R.; HUNT, Lynn. The French Revolution and Napoleon: Crucible of the Modern World. London: Bloomsbury Academic, 2017.

HUNT, Lynn. History, Why It Matters? London: Polity, 2018.

HUNT, Lynn. Inventing Human Rights: a History. New York; London: W.W. Norton, 2008.

HUNT, Lynn; REVEL, Jacques. Histories: French Constructions of the Past. New York: The New Press, 1995.

HUNT, Lynn. The Family Romance of the French Revolution. Berkeley; Los Angeles: University of California Press, 1992.

HUNT, Lynn et al. The New Cultural History. Edited with an introduction. Berkeley; Los Angeles: University of California Press, 1989.

HUNT, Lynn. Politics, Culture, and Class in the French Revolution. Berkeley; Los Angeles: University of California Press, 1984.

HUNT, Lynn. Revolution and Urban Politics in Provincial France: Troyes and Reims, 1786-1790. Stanford, US: Stanford University Press, 1978. 